\title{
Sulfasalazine: a Potent and Specific Inhibitor of Nuclear Factor Kappa B
}

\author{
Christian Wahl, ${ }^{\star}$ Susanne Liptay, ${ }^{\ddagger}$ Guido Adler, ${ }^{*}$ and Roland M. Schmid* \\ $*$ Department of Internal Medicine I and ${ }^{\ddagger}$ Department of Pediatrics, University of Ulm, D-89081 Ulm, Germany
}

\begin{abstract}
Transcription factors of the NF- $\mathrm{B} / \mathrm{Rel}$ family are critical for inducible expression of multiple genes involved in inflammatory responses. Sulfasalazine and its salicylate moiety 5-aminosalicylic acid are among the most effective agents for treating inflammatory bowel disease and rheumatoid arthritis. However, the mode of action of these drugs remains unclear. Here we provide evidence that the transcription factor NF- $\kappa \mathrm{B}$ is a target of sulfasalazine-mediated immunosuppression. Treatment of SW620 colon cells with sulfasalazine inhibited TNF $\alpha$-, LPS-, or phorbol esterinduced NF- $\kappa \mathrm{B}$ activation. NF- $\kappa \mathrm{B}-$ dependent transcription was inhibited by sulfasalazine at micro- to millimolar concentrations. In contrast, 5-aminosalicylic acid or sulfapyridine did not block NF- $\mathrm{B}$ activation at all doses tested. $\mathrm{TNF} \alpha$-induced nuclear translocation of NF- $\mathrm{B}$ was prevented by sulfasalazine through inhibition of $\mathrm{I} \kappa \mathrm{B} \alpha$ degradation. When blocking proteasome-mediated degradation of Iк $\mathrm{B} \alpha$, we could demonstrate that sulfasalazine interfered with $\mathrm{I}_{\kappa} \mathrm{B} \alpha$ phosphorylation, suggesting a direct effect on an

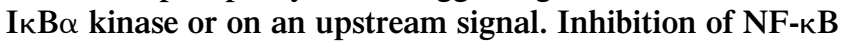
activation seems to be specific since other DNA-binding activities such as AP1 were not affected. These results demonstrate that sulfasalazine is a potent and specific inhibitor of $\mathrm{NF}-\kappa \mathrm{B}$ activation, and thus may explain some of the known biological properties of sulfasalazine. (J. Clin. Invest. 1998. 101:1163-1174.) Key words: NF-кB • AP1 • SW620 • inflammatory bowel disease $\bullet$ therapy
\end{abstract}

\section{Introduction}

Treatment of inflammatory bowel disease is restricted by its obscure pathogenesis which leads to chronic inflammation of the gastrointestinal tract. While ulcerative colitis is characterized by diffuse mucosal inflammation involving mostly the colon, Crohn's disease represents patchy transmural inflammation involving any segment of the gastrointestinal tract from the mouth to the anus. Rheumatoid arthritis, another chronic inflammatory disease of unknown cause, affects mainly the synovial membranes of multiple joints.

Sulfasalazine was synthesized in 1942 to combine an antibi-

Address correspondence to Dr. Roland M. Schmid, Department of Internal Medicine, University of Ulm, Robert-Koch-Str. 8, 89081 Ulm, Germany. Phone: +49-731-502-4305; FAX: +49-731-502-4302; E-mail: roland.schmid@medizin.uni-ulm.de

Received for publication 20 June 1997 and accepted in revised form 18 December 1997.

J. Clin. Invest.

(C) The American Society for Clinical Investigation, Inc. 0021-9738/98/03/1163/12 \$2.00

Volume 101, Number 5, March 1998, 1163-1174

http://www.jci.org otic, sulfapyridine, and an antiinflammatory agent, 5-aminosalicylic acid (5-ASA; 1). ${ }^{1}$ Sulfasalazine was the first drug with proven efficacy for ulcerative colitis (2). About $30 \%$ of sulfasalazine is absorbed in its unaltered form, whereas the rest is subjected to degradation by colonic bacteria and azo-reduction into sulfapyridine and 5-ASA(3). 70\% of sulfapyridine is absorbed opposite to 5-ASA, which appears mostly unchanged in the feces. Studies comparing equimolar doses of sulfasalazine, 5-ASA, and sulfapyridine applied topically to patients with distal colitis suggested by clinical, endoscopic, and pathological evaluations that the effects of sulfasalazine and 5-ASA were equivalent and significantly superior to sulfapyridine (4-6). Paradoxically, sulfapyridine appears to be the active moiety in rheumatoid arthritis based on the assumption that plasma viscosity and CRP are good parameters of response $(7,8)$.

The mechanisms of action by which these substances exert their effects remain a matter of debate. Numerous pharmacological and biochemical effects have been described, including immunosuppressive and modulatory actions on lymphocytes and leukocyte functions. However, it is unclear which actions are essential for the observed clinical outcome. Sulfasalazine has been found to inhibit granulocyte activation, as assessed by superoxide production and chemotaxis. In addition, sulfasalazine has been demonstrated to inhibit IL-2 synthesis and lymphocyte proliferation as well as IL-1 production by monocytes (9-14). Another possible mode of action of sulfasalazine, sulfapyridine, and 5-ASA includes toxic reactive oxygen intermediate (ROI) scavenging by neutrophils, monocytes, and macrophages (15-17).

ROIs are involved in activation of nuclear factor kappa $B$ $(\mathrm{NF}-\kappa \mathrm{B})$. NF-кB is a central mediator of the immune response. It is a multisubunit transcription factor that can rapidly activate transcription of various inflammatory cytokines, adhesion molecules, and chemokines (for review see references 18 and 19). At least five different genes belong to the NF- $\mathrm{B}$ family: NF-кB1 (p105/p50), NF-кB2 (p100/p52), RelA (p65), RelB, and c-Rel. Most commonly, NF-кB dimers are composed of the RelA (p65) and NF-кB1 (p50) or NF-кB2 (p52) subunits $(18,19)$. In most cell types, NF-кB dimers are sequestered in an inactive cytoplasmic complex by binding to its inhibitory subunit, IкB. Upon stimulation, IкB gets phosphorylated. This phosphorylation is followed by ubiquitination and rapid degradation by a proteasome-dependent pathway (2023). This pathway allows translocation of free, active $\mathrm{NF}-\mathrm{B}$ complexes into the nucleus where they bind specific DNA motifs in the promoter/enhancer regions of target genes and activate transcription.

In this study we describe sulfasalazine, a well-known drug used in treatment of inflammatory bowel disease and rheumatoid arthritis as a potent inhibitor of the transcription factor

1. Abbreviations used in this paper: 5-ASA, 5-aminosalicylic acid; ASS, acetylsalicylic acid; NAC, N-acetyl-L-cystine; NF-кB, nuclear factor kappa B; PDTC, pyrrolidine dithiocarbamate; ROI, reactive oxygen intermediate. 
NF- $\mathrm{BB}$. We show that micro- to millimolar amounts of sulfasalazine inhibited activation of NF- $\mathrm{B}$ specifically, whereas activation of AP1, another transcription factor involved in immune function regulation, was not affected at similar concentrations. NF- $\mathrm{B}$ activation in response to three different stimuli (PMA, TNF $\alpha$, and LPS) was blocked, suggesting that sulfasalazine interfered with an early common signal in these different signal transduction cascades. Sulfasalazine treatment inhibited translocation of NF-кB into the nucleus. This inhibition is paralleled by a block in IкB degradation, and is independent of protein synthesis. Most strikingly, these actions are unique to sulfasalazine, and are not shared by its moieties sulfapyridine and 5-ASA. Our data suggest that the antiinflammatory activity of sulfasalazine may rely on inhibition of the transcription factor NF-кB. These findings may explain the clinical observation that sulfasalazine influences the inflammatory responses in ulcerative colitis and Crohn's disease.

\section{Methods}

Cell culture and treatments. SW620 human colonic epithelial cells (CCL 227) were obtained from the American Type Culture Collection (Rockville, MD). Jurkat T cells and 293 human embryonic kidney cells were a generous gift from Dr. Gary J. Nabel (Howard Hughes Medical Institute, University of Michigan, Ann Arbor, MI). SW620 and 293 cells were grown in Dulbecco's modified Eagle medium, and Jurkat T cells were grown in RPMI. Media were supplemented with $10 \%$ heat-inactivated FCS, $2 \mathrm{mmol} /$ liter glutamine, and $1 \%(\mathrm{wt} / \mathrm{vol})$ penicillin/streptomycin.

Recombinant human TNF $\alpha$, LPS, PMA, pyrrolidine dithiocarbamate (PDTC), $N$-acetyl-L-cystine (NAC), acetylsalicylic acid (ASS), sulfasalazine, 5-ASA, and sulfapyridine were purchased from Sigma Chemical Co. (St. Louis, MO). Stock solutions were found to be endotoxin-free when tested in a Limnulus amebocyte lysate assay (Sigma Chemical Co.). M132 was a generous gift from Dr. Ronald T. Hay (School of Biological and Medical Science, University of St. Andrews).

NAC, ASS, sulfasalazine, 5-ASA, and sulfapyridine were dissolved in culture medium. PMA was dissolved in ethanol, and M132 was dissolved in DMSO. The respective solvents were added to control cultures. PDTC, NAC, ASS, sulfasalazine, 5-ASA, or sulfapyridine was added to the culture dishes $30 \mathrm{~min}$ before stimulation.

SW620 cells were stimulated with TNF $\alpha$, LPS, or PMA in the presence or absence of inhibitors. After the indicated time periods, cells were harvested and processed for electromobility shift assays, Western blot, or slot blot analysis.

Oligonucleotides and plasmid construction. A PCR fragment containing three tandemly repeated $\kappa \mathrm{B}$ motifs upstream of a minimal IFN- $\beta$ promoter $(-55$ to +9$)$ was generated using $5^{\prime}$ TCTCAAGGGCATCGCTCGAG 3' (sense) and 5' ACCGGAATGCCAAGCTTGCG $3^{\prime}$ (antisense) as primers and p-55Ig $\kappa$ BLuc as a template (kind gift from Dr. Takashi Fujita and Dr. David Baltimore, Department of Biology, Massachusetts Institute of Technology, Cambridge, MA). The PCR fragment was digested with Xho I and Hind III, and subcloned into pGL3 (Promega Corp., Madison, WI) to generate $3 \times \kappa$ BLuc. To clone $3 \times A P 1 L u c, 3 \times I g \kappa B L u c$ was digested with Xho I and Bam HI, and three tandemly repeated AP1 motifs were introduced as double-stranded oligonucleotides: 5' GAGCTCACTCAGTCTGTACTCAGTCTGTACTCAGTCTCCTAGG 3'. Cloning junctions and PCR products were verified by DNA sequencing. RSVp50, RSVp52, RSVp65, and RSVMAD3 (IкB $\alpha$ ) were described previously $(24,25)$. IкB $\beta$ was cloned into the Hind III and Bg II sites of RSV- $\beta$-globin (23). IкB $\beta$ was kindly provided by Dr. Sankar Ghosh (Department of Cell Biology, Yale University, New Haven, CT). Plasmid DNA was purified from bacterial cultures using a plasmid extraction kit (QUIAGEN Inc., Chatsworth, CA).
Cytoplasmic and nuclear protein extractions. Nuclear and cytoplasmic protein extracts were prepared as described earlier $(24,26)$. Protein concentrations were determined by the method of Bradford (Bio-Rad Laboratories).

Electrophoretic mobility shift assays (EMSA). EMSAs were performed as described $(24,26)$ using the $\kappa \mathrm{B}$ motif of the mouse $\mathrm{Ig}$ kappa light chain enhancer or an AP1 site (TRE: 5'AGCTTACTCAGTACTAGTACG3') as probe.

Supershift assays were performed with polyclonal antibodies

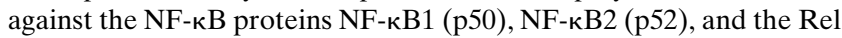
proteins RelA (p65), RelB, c-Rel, or IкB $\alpha$ (Santa Cruz Biotechnology, Santa Cruz, CA). These antibodies were added to the reaction mixtures at concentrations of 1-20 $\mu \mathrm{l}$. The samples were incubated at $4^{\circ} \mathrm{C}$ for $30 \mathrm{~min}$.

Transfections and luciferase assays. Transfections were performed as previously described (26). Inhibitors were added in the indicated amounts 30 min before stimulation with TNF $\alpha$, LPS, or PMA. Luciferase assays were performed according to the manufacturer's instructions (Promega Corp.). Luminescence was quantitated in single photon mode using a Berthold luminometer. SW620 cells transfected with reporter construct alone were taken as basal activity. Transfections were performed in at least six independent experiments. Data are presented as mean \pm SEM.

Total RNA extraction and slot blot analysis. SW620 cells were incubated with sulfasalazine or medium $30 \mathrm{~min}$ before stimulation with TNF $\alpha$ for the indicated periods. Total RNA was extracted basically as described by Chomczynski and Sacchi (27). For slot blot analysis, $20 \mu \mathrm{g}$ of RNA was transferred to a Nylon membrane (GeneScreen Plus; NEN Research Products, Boston, MA) and UV cross-linked. Prehybridization and hybridization was performed at $42^{\circ} \mathrm{C}$ in $5 \times$ SSPE, $5 \times$ Denhardt's, $1 \%$ SDS, $10 \%$ dextran sulphate, $50 \%$ deionized formamide, and $100 \mu \mathrm{g} / \mathrm{ml}$ sheared salmon sperm DNA overnight. cDNA probes were labeled with $\left.\alpha{ }^{32} \mathrm{P}\right] \mathrm{dCTP}$ by the random prime method. The following cDNA probes were used: RelA, NcoI

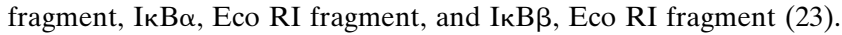
$\mathrm{I} \kappa \mathrm{B} \alpha$ was kindly provided by Dr. Albert S. Baldwin, Jr. (Lineberger Comprehensive Cancer Center, University of North Carolina). IкB $\beta$ was a gift from Dr. Sankar Ghosh (Department of Cell Biology, Yale University). Membranes were washed under high stringent conditions and exposed to $\mathrm{x}$-ray film at $-70^{\circ} \mathrm{C}$. The blots were stripped and reprobed with an $18 \mathrm{~S}$ rRNA probe.

Immunofluorescence. SW620 cells were seeded in chamber slides $3 \mathrm{~d}$ before the experiment. Cells were incubated with or without sulfasalazine $(5 \mathrm{mM})$ and/or TNF $\alpha(150 \mathrm{U} / \mathrm{ml})$. After $1 \mathrm{~h}$ of stimulation, cells were fixed in methanol $(70 \%)$ and glycine $(30 \%), \mathrm{pH} 2.5$ at $-20^{\circ} \mathrm{C}$ for $30 \mathrm{~min}$. After three washes with PBS, cells were permeabilized using TritonX100 $0.1 \%$ for $4 \mathrm{~min}$, and were washed three times with PBS and PBS/fishskin gelatine (0.2\%), respectively. Anti-p65 (Santa Cruz Biotechnology) was added (1:200) at room temperature for $30 \mathrm{~min}$. After washing, Cy3-conjugated goat anti-rabbit (DianovaImmunotech, Hamburg, Germany) was added $(1: 1,000)$ for $1 \mathrm{~h}$. After final washes, slides were stored at $4^{\circ} \mathrm{C}$ until pictures were taken using a confocal laser scanning microscope (Carl Zeiss, Inc., Thornwood, NY).

Western blotting. Nuclear or cytoplasmic protein extracts were diluted in SDS-PAGE loading buffer. The amount of protein loaded was measured by Bradford assay. Recombinant NF-кB1 (p50), NFкB2 (p52), RelA (p65), ІкB $\alpha$, or ІкB $\beta$ was prepared by transfecting 293 human embryonic kidney cells with the respective eukaryotic expression vector as previously described and loaded as controls (26). After SDS-PAGE, the gels were transferred to 0.2- $\mu \mathrm{m}$ PVDF membranes for $2 \mathrm{~h}$ at $4^{\circ} \mathrm{C}$ (Schleicher \& Schuell, Inc., Keene, NH). Blots were blocked with $5 \%$ Blotto ( $5 \%$ dry milk, $50 \mathrm{mM}$ Tris- $\mathrm{HCl}, \mathrm{pH} 7.5$, $50 \mathrm{mM} \mathrm{NaCl}, 1 \mathrm{mM}$ EDTA, and $1 \mathrm{mM}$ DTT) overnight at $4^{\circ} \mathrm{C}$. The next day blots were rinsed with TBST $(150 \mathrm{mM} \mathrm{NaCl}, 10 \mathrm{mM}$ Tris$\mathrm{HCl}, \mathrm{pH} 8$, and $0.05 \%$ Tween 20 ) for $30 \mathrm{~min}$. Blots were incubated

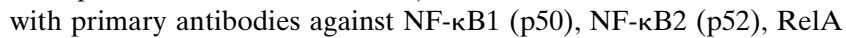
(p65), IкB $\alpha$, or IкB $\beta$ (Santa Cruz Biotechnology). Antibodies were added at a dilution of 1:1,000 for $2 \mathrm{~h}$ at room temperature, washed 
with TBST containing $0.2 \%$ Tween 20 , and incubated for $2 \mathrm{~h}$ with the secondary antibody, goat anti-rabbit IgG-peroxidase (DianovaImmunotech) at a dilution of 1:10,000 in 5\% Blotto. Subsequently, blots were washed three times with TBST containing $0.2 \%$ Tween 20 . Blots were developed for $60 \mathrm{~s}$ with ECL reagents (Amersham Corp., Arlington Heights, IL).

\section{Results}

$N F-\kappa B /$ Rel activation and $\kappa B$-dependent transcription in $S W 620$ cells. SW620 cells were used as a model system for studying $\mathrm{NF}-\kappa \mathrm{B}$ activation in vitro. This cell line displays important functional and morphological characteristics of normal human intestinal epithelial cells (28). Furthermore, this colon cell line responds to treatment with TNF $\alpha$, LPS, and IL-1 $\beta$ (29). To study the effect of different doses of TNF $\alpha$ on NF-кB binding activity in these cells, electromobility shift assays were performed. SW620 cells were incubated with increasing doses of $\mathrm{TNF} \alpha$, and nuclear extracts were prepared and incubated with an end ${ }^{32} \mathrm{P}$-labeled DNA oligonucleotide containing the recog-

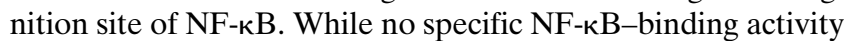
was detected in the unstimulated state (Fig. $1 A$, lane 1 ), TNF $\alpha$ induced NF-кB binding in a gradual manner (lanes 2-6). Maximal activation of inducible DNA binding activity required 150

\section{A}

\section{TNF- $\alpha U$ \\ $1050,0552^{\circ}$}

B

$\mathrm{NF}-\kappa \mathrm{B}$
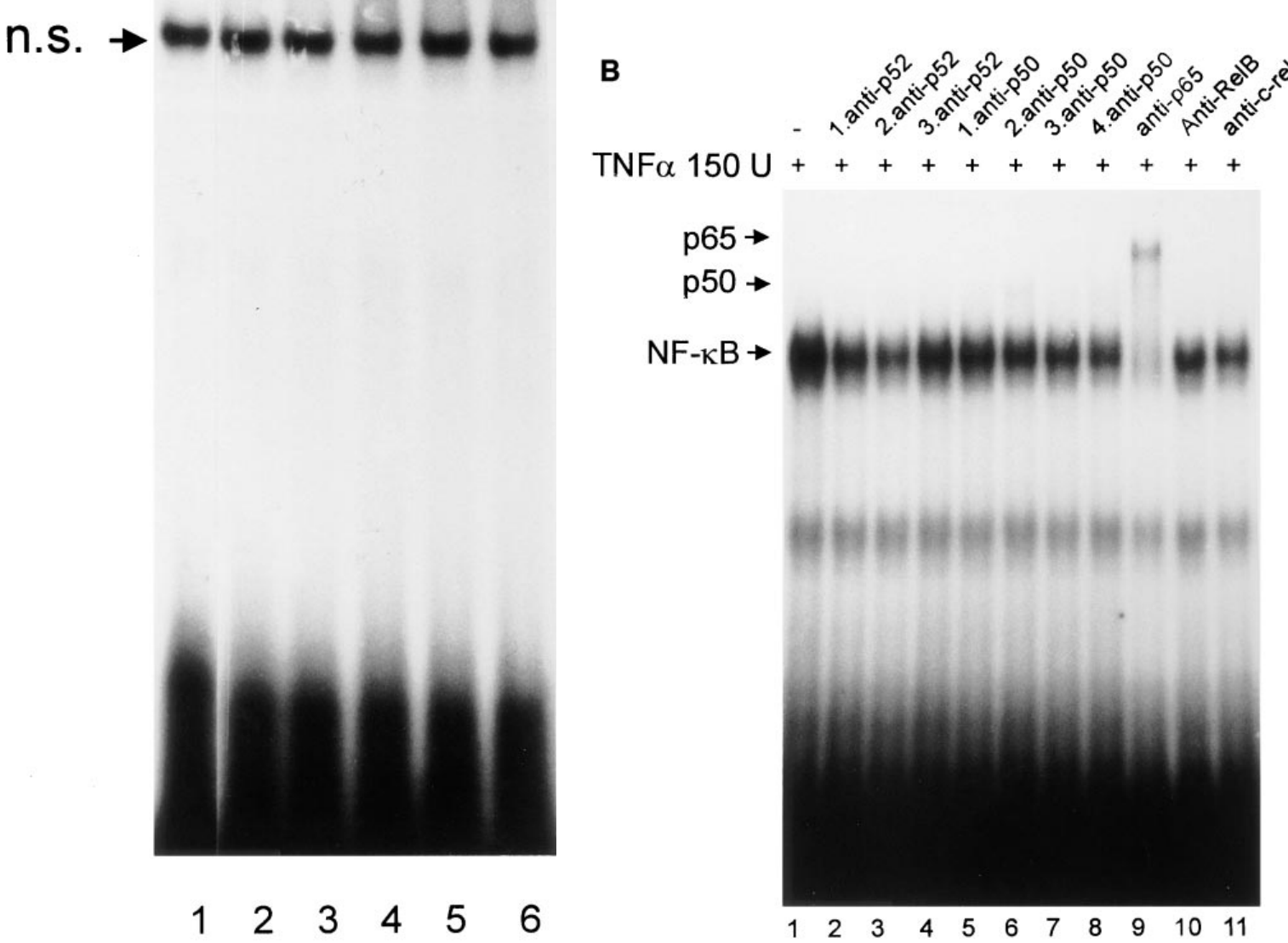

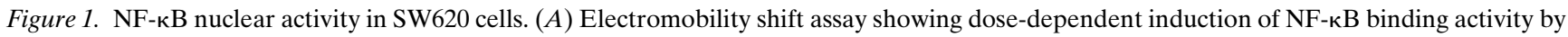
TNF $\alpha$. SW620 cells were untreated (lane 1) or incubated with various doses of TNF $\alpha$. Nuclear extracts were prepared, and equal amounts were reacted with ${ }^{32} \mathrm{P}$-labeled DNA probe encompassing the $\kappa \mathrm{B}$ motif of the mouse kappa light chain enhancer. Samples were analyzed on a native $1 \times$ Tris-glycine-EDTA polyacrylamide gel. The arrows indicate the position of the $\mathrm{\kappa B}$-specific DNA binding activity and the position of a nonspecific (n.s.) activity. (B) Supershift assay identifying the subunit composition of NF-кB complexes in TNF $\alpha$-induced SW620 colon cells (lanes 1-11). After treatment with TNF $\alpha(150 \mathrm{U} / \mathrm{ml}$ for $1 \mathrm{~h})$, a panel of different antibodies was added as indicated (lanes 2-11). 
$\mathrm{U} / \mathrm{ml} \mathrm{TNF} \alpha$. A faster-migrating, nonspecific protein-DNA complex was not affected by the various treatments, and provided an internal control for the amount and integrity of nuclear cell extracts.

The specificity of NF-кB DNA binding induced by TNF $\alpha$ was confirmed in competition experiments. Incubation with an excess of mutated oligonucleotide or an unrelated oligonucleotide spanning an AP1 binding site did not antagonize NF- $\mathrm{B}$ binding, whereas competition with a 100 -fold excess of unlabeled oligonucleotide led to inhibition of binding activity (data not shown).

Because NF- $\kappa \mathrm{B}$ complexes may constitute a variety of different homo and heterodimers, the subunit compositions of the TNF $\alpha$-induced DNA complex were analyzed by supershift assays (Fig. $1 B$ ). Rabbit antisera against NF-кB2 (p52; lanes 2-4), NF-кB1 (p50; lanes 5-8), RelA (p65; lane 9), RelB (lane 10), and c-Rel (lane 11) were added to nuclear extracts of SW620 cells (lanes 1-11) stimulated with $150 \mathrm{U} / \mathrm{ml} \mathrm{TNF} \alpha$ for $1 \mathrm{~h}$. Anti-p65 retarded the NF-кB specific DNA complex. In addition, anti-p50 induced a slight supershift (lane 6), anti-p52 and anti-c-Rel did not induce a supershift in these cells. When gels were exposed for long periods, the p50-specific supershift was more clearly detectable. These data indicate the presence of RelA (p65) and NF-кB1 (p50) in the TNF $\alpha$-induced NF-кB complex in SW620 cells.

TNF $\alpha$ induced NF-kB in SW620 cells within 10 min. Maximal induction was observed after $1 \mathrm{~h}$ of treatment and persisted for $4 \mathrm{~h}$ (data not shown). In addition, PMA induced NF$\kappa \mathrm{B}$ in these cells in a dose- and time-dependent manner (data not shown).

$\mathrm{NF}-\mathrm{\kappa B}$ binding sites in promoters and enhancers of genes serve as response elements that confer activation after treatment with TNF $\alpha$, LPS, phorbol ester, and other stimuli $(18,19$, $21,22)$. In the following experiments, luciferase constructs under the control of three $\kappa \mathrm{B}$ sites $(3 \times \mathrm{XIg \kappa} \mathrm{BLuci})$ or a control plasmid without $\kappa \mathrm{B}$ sites were transfected into SW620 cells. $24 \mathrm{~h}$ after transfection, cells were treated for an additional $24 \mathrm{~h}$ with either TNF $\alpha$ or LPS. TNF $\alpha$ caused strong induction of luciferase activity (Fig. 2 A). $200 \mathrm{U} / \mathrm{ml}$ of TNF $\alpha$ induced a $25-$ fold increase in luciferase activity compared with cells not exposed to TNF $\alpha$. Treatment of cells with LPS showed effects very similar to those with $\mathrm{TNF} \alpha$ (Fig. $2 \mathrm{~B}$ ). A maximum of $\kappa \mathrm{B}-$ dependent transcription was observed with $50 \mathrm{ng} / \mathrm{ml} \mathrm{LPS}$, which was not further increased by higher doses. Treatment with $20 \mathrm{ng} / \mathrm{ml}$ PMA augmented luciferase activity as strongly as did treatment with $150 \mathrm{U} / \mathrm{ml} \mathrm{TNF}$ (data not shown). The increase in luciferase activity was completely dependent on the presence of $\kappa \mathrm{B}$ sites since the control plasmid lacking the $\kappa \mathrm{B}$ elements did not respond to TNF $\alpha$, LPS, or PMA.

Effect of antioxidants on $N F-\kappa B$ activation in SW620 cells. Involvement of ROI in the effects of TNF $\alpha$, LPS, and IL-1 $\beta-$ mediated NF-кB activation has been demonstrated in lymphocytes, macrophages, and endothelial cells (30, 31). Radical scavenging agents such as PDTC, NAC, or ASS can easily react with and thereby eliminate ROIs, resulting in inhibition of $\mathrm{NF}-\kappa \mathrm{B}$ activation (30-32). To investigate the effect of antioxidants on NF- $\kappa$ B activation in SW620 cells, cells were preincubated with 10 or $100 \mu \mathrm{M}$ PDTC, $10 \mathrm{mM}$ NAC, or $5 \mathrm{mM}$ ASS. Subsequently, cells were stimulated with $150 \mathrm{U} / \mathrm{ml} \mathrm{TNFa}$ for an additional $1 \mathrm{~h}$. Nuclear extracts were prepared and electromobility shift assays were performed using ${ }^{32} \mathrm{P}$-labeled oligonucleotide containing the Ig- $\kappa \mathrm{B}$ motif. While no specific NF-
A

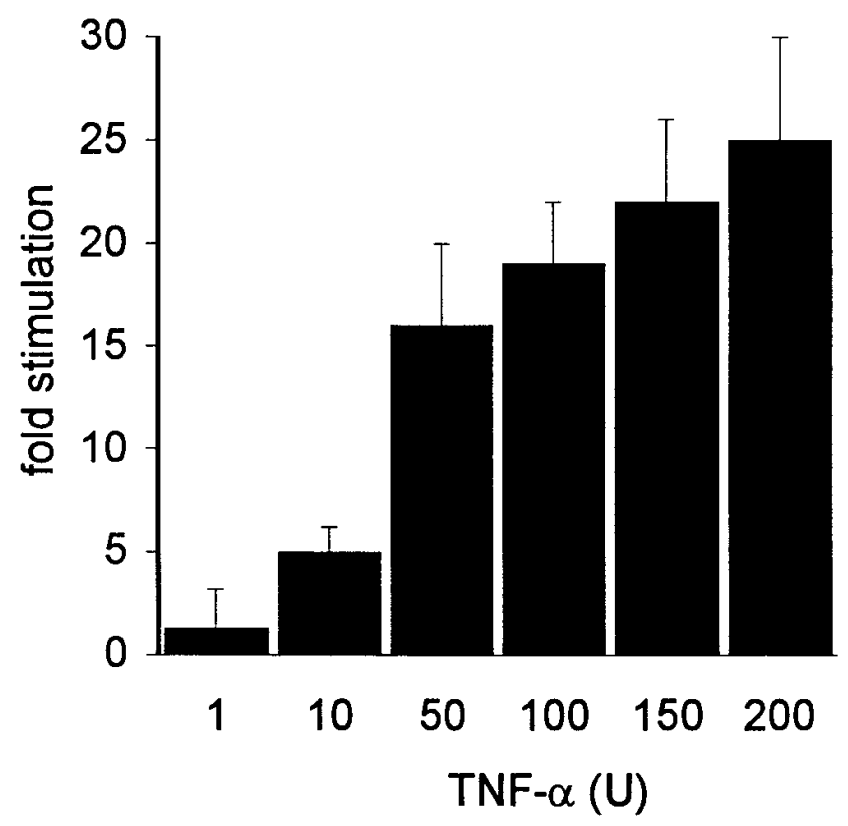

B

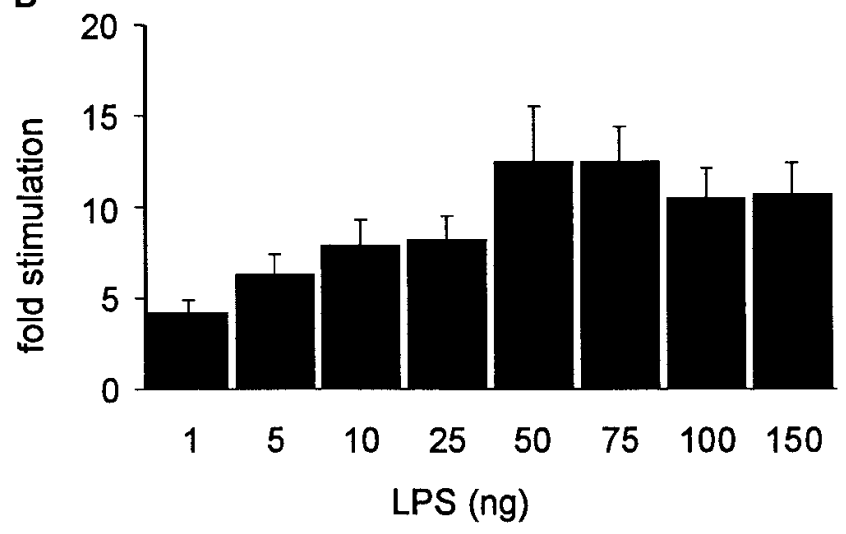

Figure 2. Stimulation of NF-кB-dependent transcription by TNF $\alpha$ and LPS. ( $A$ ) SW620 cells were transfected using the calcium phosphate method with a three-copy $\kappa \mathrm{B}$ reporter construct (3xIgкBLuc). $24 \mathrm{~h}$ after transfection, TNF $\alpha$ was added to the media at the indicated doses. After another $24 \mathrm{~h}$, cell extracts were harvested and luciferase activity was determined. The fold induction is relative to luciferase activity of the vector without $\kappa \mathrm{B}$ sites. $(B)$ In a second set of experiments, cells were stimulated with LPS. Doses of LPS are indicated. Values are expressed as the mean of at least six independent experiments \pm SEM.

$\mathrm{\kappa B}$ binding activity was detected in the unstimulated state (Fig. $3 A$, lane 1), $150 \mathrm{U} / \mathrm{ml}$ TNF $\alpha$ induced strong NF-кB binding activity (lane 2 ) that was reduced to $\sim 50 \%$ when cells were preincubated with $100 \mu \mathrm{M}$ PDTC (lane 3), but was unaffected with $10 \mu \mathrm{M}$ PDTC, $10 \mathrm{mM}$ NAC, or $5 \mathrm{mM}$ ASS (lanes 4-6).

To assess the effect of antioxidants on NF-кB-dependent transcription, SW620 cells were transfected with the $к B$-dependent luciferase reporter construct. Cells were pretreated with $1-100 \mu \mathrm{M}$ of PDTC, $10 \mathrm{mM}$ NAC, $5 \mathrm{mM}$ ASS, or medium for $30 \mathrm{~min}$ followed by stimulation with $150 \mathrm{U} / \mathrm{ml} \mathrm{TNF} \alpha$ for $24 \mathrm{~h}$. Thereafter, cells were lysed, and extracts were assayed for luciferase activity. Treatment with PDTC resulted in dose- 


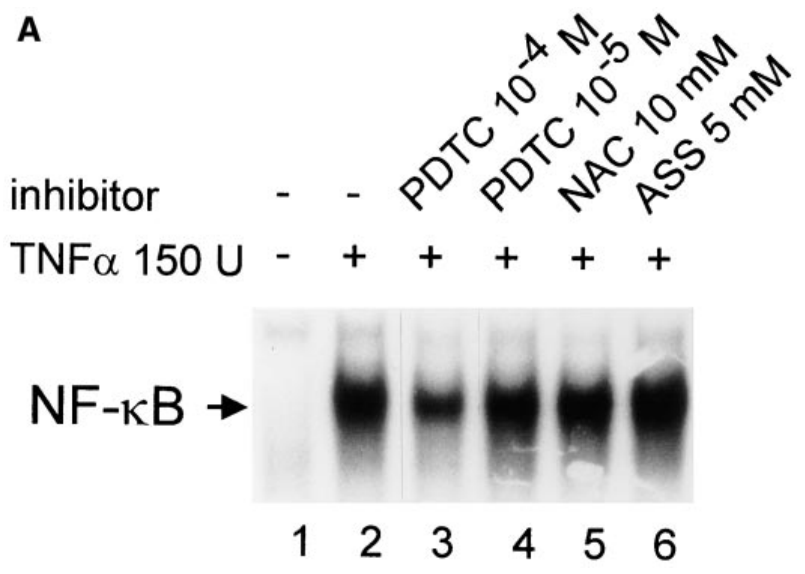

B

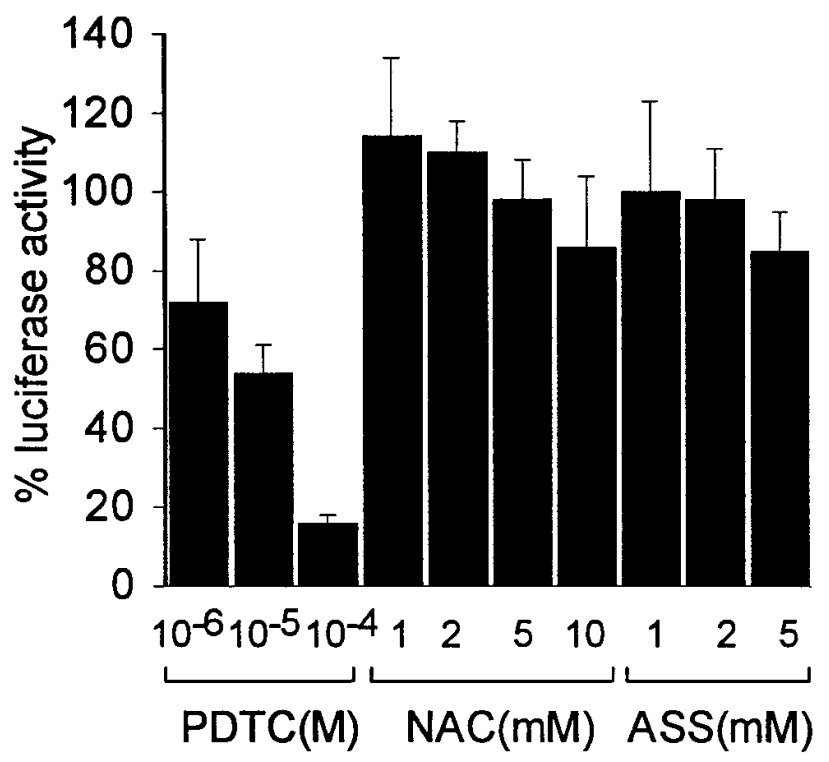

Figure 3. Effect of antioxidants on NF-кB activation in SW620 cells. (A) SW620 cells were treated for 30 min with 100 or $10 \mu \mathrm{M}$ PDTC, 10 $\mathrm{mM}$ NAC, or $5 \mathrm{mM}$ ASS before stimulation with TNF $\alpha(150 \mathrm{U} / \mathrm{ml})$. After another $1 \mathrm{~h}$, nuclear extracts were prepared from control and treated cells, and equal amounts of protein $(5 \mu \mathrm{g})$ were used in electromobility shift analysis with the $\kappa \mathrm{B}$ motif of the mouse kappa light chain enhancer. Specific NF-кB complexes are shown. (B) SW620 cells were transfected with $5 \mu \mathrm{g}$ of DNA of a reporter construct containing $3 \mathrm{\kappa B}$ motifs in front of a minimal $\beta$-interferon promoter and the luciferase reporter gene ( $\left.3 \times I_{\text {Ig }} B L u c\right)$, or a control plasmid without $\mathrm{\kappa B}$ sites. After transfection, cultures were treated with 100,10 , or $1 \mu \mathrm{M}$ PDTC, $10 \mathrm{mM}$ NAC, or $5 \mathrm{mM}$ ASS after stimulation with 150 $\mathrm{U} / \mathrm{ml} \mathrm{TNF} \alpha$. Extracts were prepared after $24 \mathrm{~h}$, and were assayed for luciferase activity. Values were expressed as percent luciferase activity compared with cells stimulated with TNF $\alpha$ only. At least six independent experiments were performed. Values are expressed as mean \pm SEM.

dependent suppression of luciferase activity. The strongest effect was seen with $100 \mu \mathrm{M}$ PDTC, which decreased luciferase activity to $20 \%$ (Fig. $3 \mathrm{~B}$ ). This effect was in the same range as that reported for other cell lines (31). NAC and ASS did not affect luciferase activity at the doses tested, suggesting that higher concentrations are required to inhibit NF-kB-depen- dent transcription in these cells. Previously, it was shown in lymphocytes that NAC and ASS were most effective at higher doses $(30,32,33)$. However, we were unable to use these high doses since at these concentrations, the $\mathrm{pH}$ of the medium was affected and the compounds did not dissolve completely. When cells were treated with PMA or LPS, similar results were obtained (data not shown).

Sulfasalazine is a specific inhibitor of $\kappa B$ binding activity. Since there is evidence that sulfasalazine and its moieties 5-ASA and sulfapyridine are potent antiinflammatory agents, we were interested in whether these substances affect NF- $\kappa \mathrm{B}$ activation. Therefore, SW620 cells were pretreated for $30 \mathrm{~min}$ with medium 5-ASA, sulfasalazine, or sulfapyridine at 1-, 2-, or 5-mM concentrations, respectively. After stimulation with 150 $\mathrm{U} / \mathrm{ml} \mathrm{TNF} \alpha$ for an additional $1 \mathrm{~h}$, nuclear extracts were prepared and incubated with a $\kappa \mathrm{B}$-specific probe (Fig. 4, lanes $1-12$ ). $\mathrm{TNF} \alpha$ induced a strong NF-кB binding activity (lane 2) which was specifically competed by a 20 -fold molar excess of unlabeled competitor oligonucleotide (lane 3). Cells pretreated with 5-ASA showed a pattern of DNA binding activity that was not distinct from that of control cells stimulated with $\mathrm{TNF} \alpha$ (lanes 4-6). In contrast, incubation with sulfasalazine

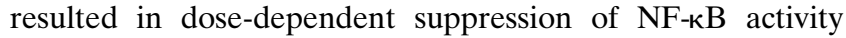
(lanes 7-9). In cells treated with sulfapyridine, NF-кB-binding activity was not affected at all doses tested (lanes 10-12). These data suggest sulfasalazine as a potent inhibitor of $\mathrm{NF} \kappa \mathrm{B}$ activation, whereas its moieties 5-ASA and sulfapyridine are not. In vitro addition of sulfasalazine to the binding reaction of extracts from TNF $\alpha$-treated SW620 cells did not inhibit binding to the $\mathrm{\kappa B}$ motif (data not shown). To test the specificity of sulfasalazine, the same nuclear extracts of SW620 cells were tested for DNA binding activity of other transcription factors. AP1 binding activity was assayed using ${ }^{32} \mathrm{P}$-labeled TRE probe (Fig. 4, lanes 13-24). Specific AP1 activity was detectable in uninduced and TNF $\alpha$-induced SW620 cells (compare lane 15 to lanes 13 and 14). Sulfasalazine could not prevent AP1 binding activity (lanes 19-21), indicating that sulfasalazine did not interfere with other PKC-regulated events in intact cells. Again, 5-ASA (lanes 16-18) and sulfapyridine (lanes 22-24) had no significant influence on DNA binding activity. In conclusion, sulfasalazine seems to be a potent and fairly specific inhibitor of NF-kB binding activity.

Sulfasalazine is a potent inhibitor of $N F-\kappa B$-dependent transactivation. To test whether sulfasalazine, 5-ASA, or sulfapyridine can suppress induction of luciferase activity after TNF $\alpha$ or LPS stimulation, SW620 cells were transfected with a

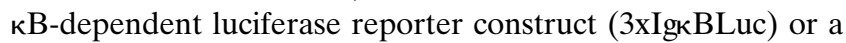
respective control plasmid. After $18 \mathrm{~h}$, cells were treated with increasing doses of sulfasalazine, 5-ASA, or sulfapyridine 30 min before stimulation with TNF $\alpha$, LPS, or PMA. Cells were harvested after an additional $24 \mathrm{~h}$, and were assayed for luciferase activity. Induction of luciferase activity by $\mathrm{TNF} \alpha$ was inhibited by sulfasalazine in a dose-dependent fashion (Fig. $5 A$ ). Half-maximal inhibition was detected between 0.5 and $1 \mathrm{mM}$ sulfasalazine, whereas $5 \mathrm{mM}$ sulfasalazine suppressed luciferase activity to basal levels. These effects are in the same concentration range as the inhibitory effect of sulfasalazine on NF- $\kappa \mathrm{B}$ binding activity seen by electromobility shift assay (Fig. 4). Dose-dependent suppression was also detected when NF$\kappa \mathrm{B}$ was activated by LPS (Fig. $5 B$ ), or PMA (data not shown).

It is in accordance with the DNA binding data that the sulfasalazine moieties 5-ASA and sulfapyridine were less potent 


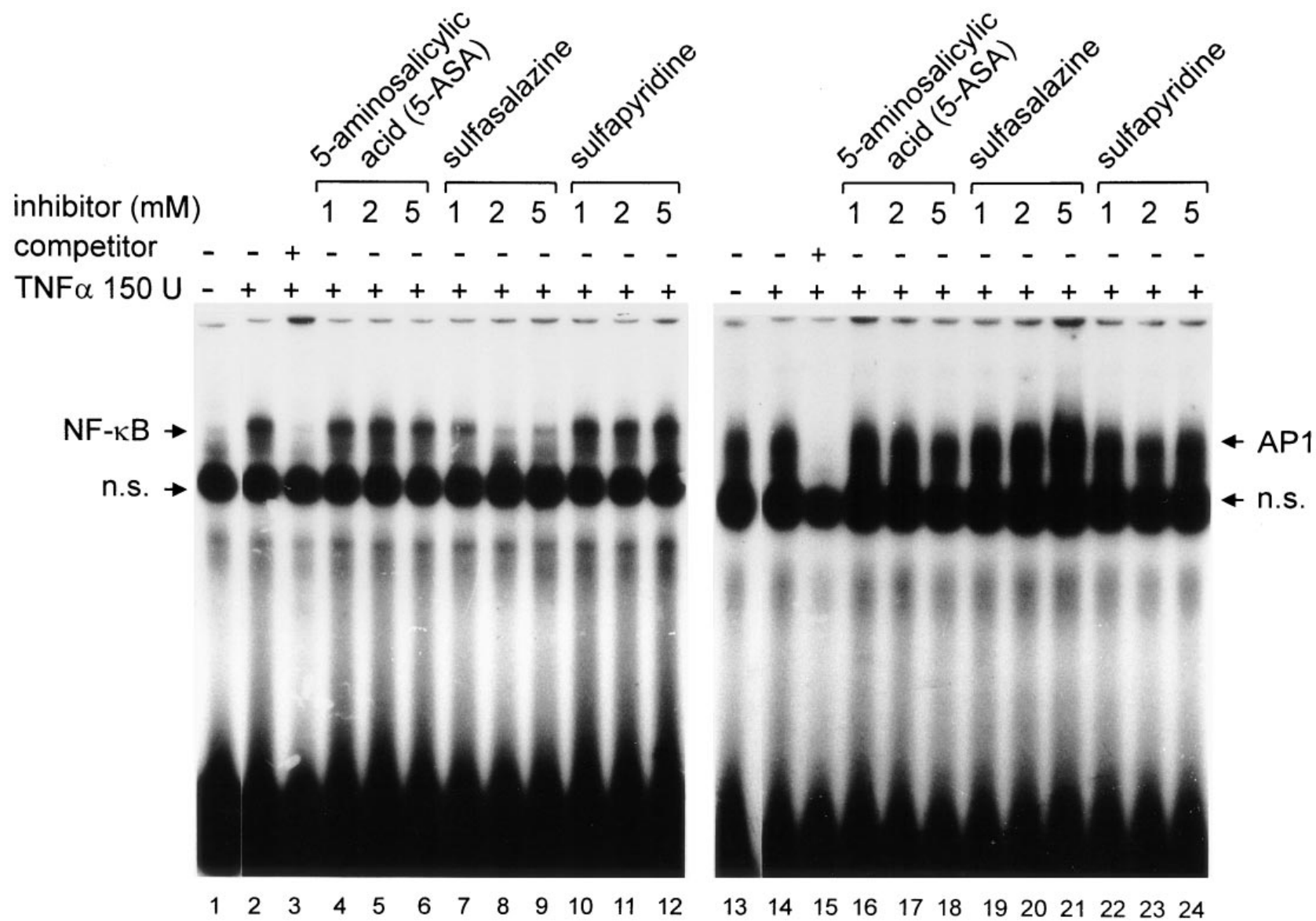

Figure 4. Sulfasalazine is a specific inhibitor of NF-кB activation. SW620 cells were left untreated or incubated with 5-ASA, sulfasalazine, or sulfapyridine at various doses as indicated followed by stimulation with TNF $\alpha(150 \mathrm{U} / \mathrm{ml})$. Nuclear extracts were prepared, and equal amounts were reacted with ${ }^{32} \mathrm{P}$-labeled DNA probes encompassing the $\kappa \mathrm{B}$ motif of the mouse kappa light chain enhancer (lanes 1-12) or a TRE-motif (lanes 13-24). Samples were analyzed on a native $1 \times$ TGE polyacrylamide gel. The arrows indicate the positions of the specific NF-кB and AP1 DNA binding activities, and of a nonspecific (n.s.) binding activity.

in inhibiting $\kappa \mathrm{B}$-dependent transcription. 5-ASA, even at the highest concentration ( $5 \mathrm{mM})$, almost did not affect luciferase activity. Sulfapyridine mediated only a marginal reduction of luciferase activity (Fig. 5, $C$ and $D$ ). Similar results were obtained in Jurkat $\mathrm{T}$ cells (Fig. $5 E$ ). The inhibitory effects of sulfasalazine were specific since the activity of an AP1 reporter construct was not suppressed by sulfasalazine (data not shown).

Sulfasalazine did not inhibit RelA mRNA levels, but rather significantly decreased $I \kappa B \alpha m R N A$ levels. To investigate further the mode of sulfasalazine-mediated inhibition of NF- $\mathrm{B}$ activation, we analyzed the effect of sulfasalazine on RelA (p65) mRNA levels. SW620 cells were treated with sulfasalazine $30 \mathrm{~min}$ before stimulation with TNF $\alpha$, and were harvested at various time points as indicated (Fig. 6). Slot blot analyses were performed to assay the effect of sulfasalazine on steadystate mRNA levels of RelA (p65) and IкB $\alpha$. RelA (p65) mRNA did not increase after stimulation with $\mathrm{TNF} \alpha$, and did not show significant changes after treatment with sulfasalazine. However, IкB $\alpha$ mRNA increased 15 -fold 30 min after $\mathrm{TNF} \alpha$ induction, and declined to fourfold after $6 \mathrm{~h}$. After $12 \mathrm{~h}$, the $\mathrm{I} \kappa \mathrm{B} \alpha \mathrm{mRNA}$ levels were down to basal. This increase was completely suppressed by sulfasalazine pretreatment. In addi- tion, basal IкB $\alpha$ levels seemed to be decreased. Previously, it was shown that $\mathrm{I} \kappa \mathrm{B} \alpha$ expression was strongly induced by NF$\kappa \mathrm{B}(34)$. Once NF- $\mathrm{BB}$ is activated and present in the nucleus, it induces $\mathrm{I} \kappa \mathrm{B} \alpha$ transcription via $\kappa \mathrm{B}$ sites present in the I $\mathrm{B} \alpha$ promoter (35). This induction is thought to function as negative feedback regulation. Resynthesized $\mathrm{I} \kappa \mathrm{B} \alpha$ interacts with $\mathrm{NF}-\kappa \mathrm{B}$ complexes to terminate NF- $\mathrm{B}$ activation and maintain $\mathrm{NF}-\kappa \mathrm{B}$ inducibility. Our results suggest that induction of $\mathrm{I} \kappa \mathrm{B} \alpha$ mRNA by TNF $\alpha$ can be abolished by sulfasalazine, and therefore completely suppress $\kappa \mathrm{B}$-dependent transcription and this negative feedback mechanism. mRNA levels of IкB $\beta$ were not affected after $\mathrm{TNF} \alpha$ treatment, or by addition of sulfasalazine (data not shown).

Sulfasalazine blocks nuclear translocation of RelA. In unstimulated cells, NF-кB heterodimers are kept as inactive complexes in the cytoplasm by inhibitory proteins such as $\mathrm{I}_{\kappa} \mathrm{B} \alpha$ and $\mathrm{I} \kappa \mathrm{B} \beta$. After cell stimulation, IкBs are phosphorylated and degraded, and free dimers translocate into the nucleus. To investigate whether sulfasalazine inhibited nuclear translocation of RelA (p65)-containing complexes, SW620 cells were left untreated, or were stimulated with $\mathrm{TNF} \alpha$ in the presence or absence of sulfasalazine. Cells were grown on chamber slides, treated as indicated, fixed, and the location of RelA (p65) was 
A

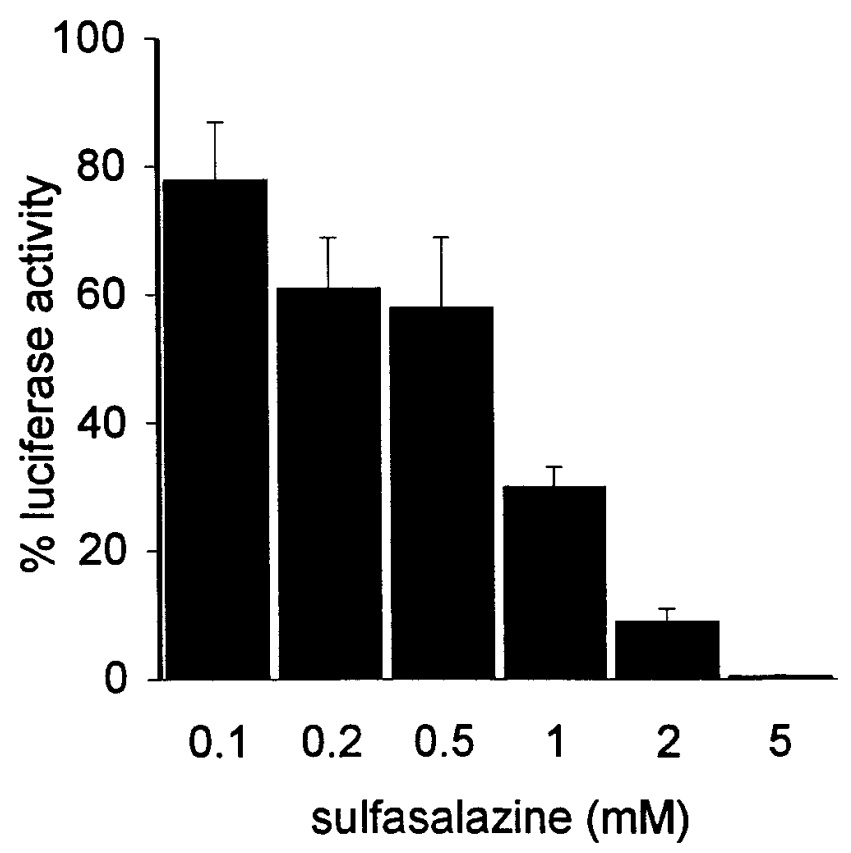

B

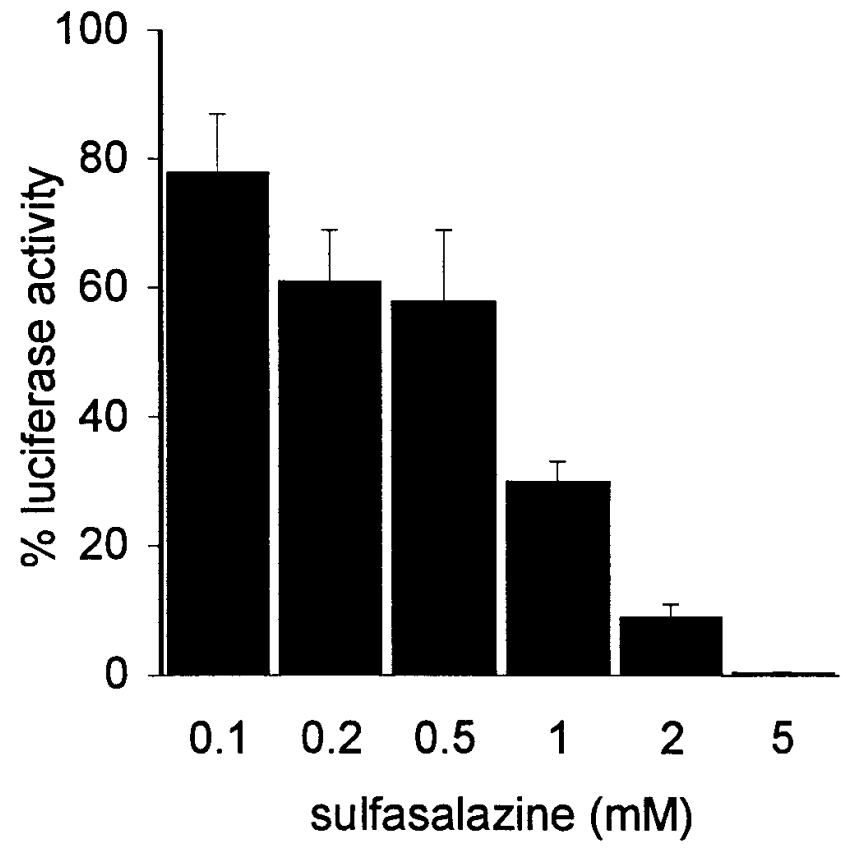

D

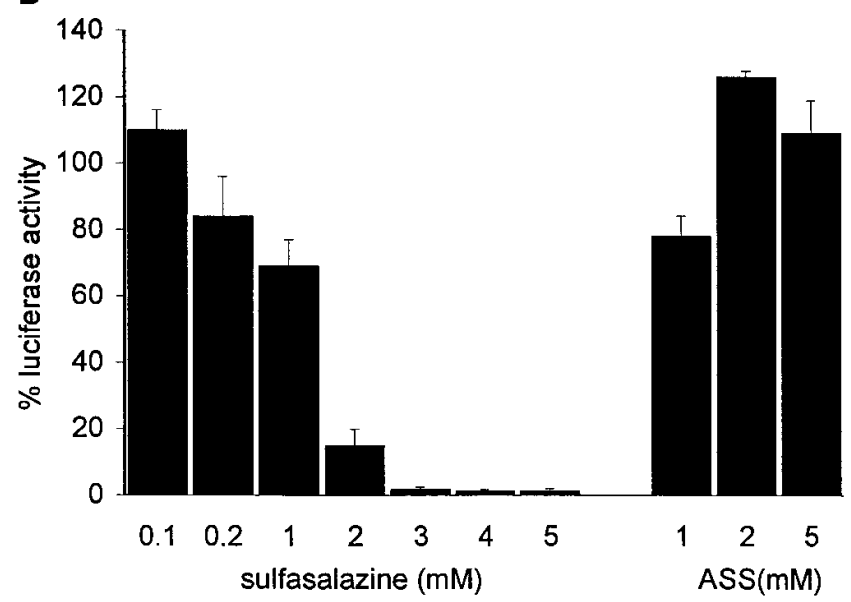

Figure 5. Sulfasalazine blocks TNF $\alpha$ and LPS-induced NF-кB-dependent transcription but its compounds 5-ASA and sulfapyridine are ineffective. (A) SW620 cells were transfected with the 3xIgкBLuc reporter construct. After $18 \mathrm{~h}$, cells were incubated with either medium alone or with sulfasalazine $(A$ and $B), 5$-ASA, or sulfapyridine $(C)$ at the indicated doses $30 \mathrm{~min}$ before stimulation with TNF $\alpha 150 \mathrm{U} / \mathrm{ml}(A$ and $C)$, or $150 \mathrm{ng} /$ $\mathrm{ml}$ LPS $(B)$. Jurkat T cells were transfected with the $3 \mathrm{xIg}_{\kappa}$ BLuc reporter construct and treated with sulfasalzine, ASS, and TNF as described for SW620 cells $(D)$. After $24 \mathrm{~h}$ cells were harvested, and luciferase activity was determined. Values are expressed as the mean of at least six independent experiments \pm SEM.

determined by immunofluorescence using an antibody specific against RelA (p65). In the unstimulated state, RelA (p65) localized exclusively to the cytoplasm (Fig. $7 A$ ). The staining pattern did not change upon treatment with sulfasalazine alone (Fig. 7 B). After stimulation with TNF $\alpha$, RelA (p65) was also found in the nucleus (Fig. $7 C$ ). However, treatment with $\mathrm{TNF} \alpha$ plus sulfasalazine resulted in exclusive cytoplasmic staining indistinguishable from that of unstimulated cells (Fig. $7 \mathrm{D}$ ). These results indicate that sulfasalazine prevents nuclear translocation of RelA (p65). Therefore, we were interested to analyze the effects of sulfasalazine and its compounds 5-ASA and sulfapyridine on nuclear protein levels of RelA (p65), NF$\kappa \mathrm{B} 1$ (p50), and NF-кB2 (p52) in more detail. Cells were preincubated with sulfasalazine, 5-ASA, sulfapyridine, or with medium alone followed by stimulation with $\mathrm{TNF} \alpha$. Nuclear extracts were prepared, and Western blot analysis was performed with specific antibodies (Fig. $7 \mathrm{E}$ ). A strong RelA (p65) signal was detected in nuclear extracts from cells stimulated with $\mathrm{TNF} \alpha$ (lane 2) compared with unstimulated cells (lane 1). Pretreatment with sulfasalazine prevented translocation of RelA (p65; lane 4), while RelA (p65) was not affected by similar doses of 5-ASA (lane 3) and sulfapyridine (lane 5). 

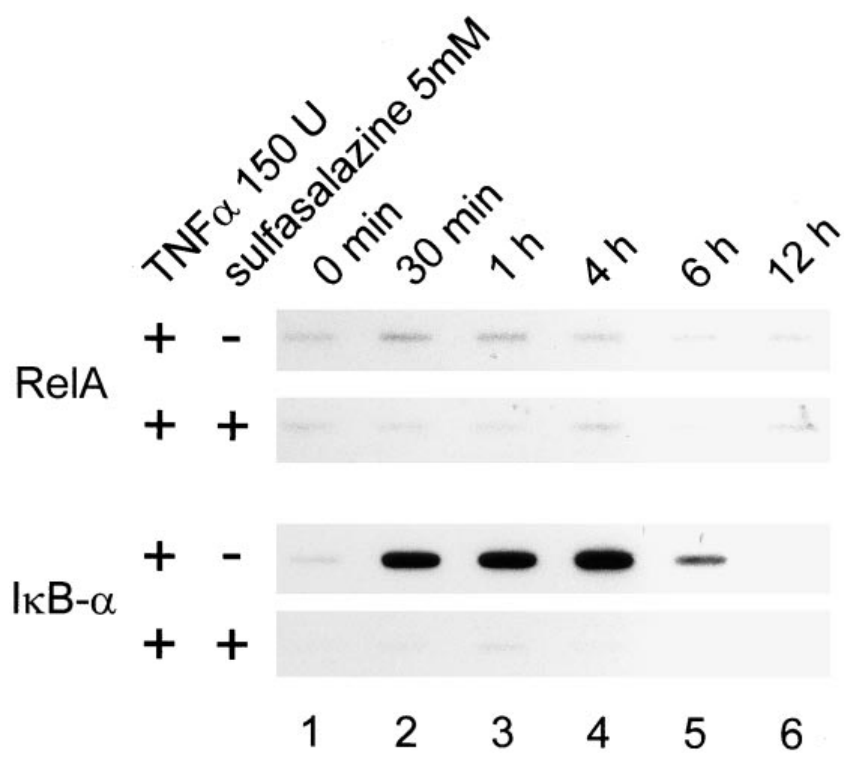

Figure 6. Sulfasalazine did not affect RelA (p65), but significantly decreased IкB $\alpha$ steady-state mRNA levels. Cells were treated with $5 \mathrm{mM}$ sulfasalazine $30 \mathrm{~min}$ before $\mathrm{TNF} \alpha(150 \mathrm{U} / \mathrm{ml})$ stimulation, and were harvested at the indicated times. RNA was isolated, blotted on nylon membranes, and hybridized to probes specific for RelA (p65) or $\mathrm{I} \kappa \mathrm{B} \alpha$.

NF-кB1 (p50) and NF-кB2 (p52) were detected in small amounts, and expression was not found to be affected by all treatments. In SW620 cells RelA (p65) seems to be the predominant NF- $\mathrm{BB}$ subunit consistent with the results obtained in supershift assays (see Fig. 4).

Sulfasalazine interferes with I $\kappa \alpha \alpha$ degradation. These results do not allow a conclusion regarding the stage at which blockage of NF-кB activation occurs. In light of these observations, we tested whether degradation of I $\mathrm{B} \alpha$ could take place in the presence of sulfasalazine. SW620 cells were pretreated with sulfasalazine for $30 \mathrm{~min}$, and were subsequently stimulated with TNF $\alpha$. Cells were harvested at different time points as indicated, and cytoplasmic and nuclear proteins were extracted. Cytoplasmic and nuclear extracts were analyzed by Western blotting using anti-IкB $\alpha$ and anti-RelA (p65) antibodies. The cytoplasmic $\mathrm{I} \kappa \mathrm{B} \alpha$ signal almost completely disappeared after 30 min of TNF $\alpha$ treatment, concomitant with an increase of RelA (p65) in the nucleus. After $1 \mathrm{~h}$ of TNF $\alpha$ treatment, IкB $\alpha$ returned to the original level (Fig. 8; compare lanes 2-4). This time-dependent degradation of Iк $\mathrm{B} \alpha$ was blocked by sulfasalazine (compare lanes 7 and 3 ). In addition, IкB $\alpha$ levels seemed to be reduced in the presence of sulfasalazine. In contrast, I $\mathrm{B} \beta$ protein levels were not affected (data not shown). No changes on RelA (p65) expression were observed after sulfasalazine treatment (lanes 6-9). Our results demonstrate that both activation of NF- $\mathrm{B}$ and loss of $\mathrm{I} \kappa \mathrm{B} \alpha$ are inhibited in the presence of sulfasalazine. When SW620 cells were pretreated with sulfasalazine in the presence or absence of cycloheximide, no difference was observed, suggesting that the suppressive effect mediated by sulfasalazine is independent of de novo protein synthesis (data not shown).

Sulfasalazine appears to prevent I $\kappa \alpha$ phosphorylation. It has been reported that $\mathrm{I}_{\kappa} \mathrm{B} \alpha$ is subject to both phosphorylation and proteolysis in the process of NF- $\mathrm{KB}$ activation (20-22). Proteolysis of Iк $\mathrm{B} \alpha$ follows immediately after phosphorylation, and is dependent on the activity of proteasomes. In different cell types, specific proteasome inhibitors can prevent I $\kappa \mathrm{B} \alpha$ degradation, thus allowing detection of a slower-migrating phosphorylated form of $\mathrm{I} \kappa \mathrm{B} \alpha$ that usually is not observed because of the high turnover of phosphorylated IкB $\alpha$. Therefore, we were interested to investigate the effect of the proteasome inhibitor MG132 on SW620 cells in the presence and absence of sulfasalazine. Again, $30 \mathrm{~min}$ after TNF $\alpha$ treatment, cytoplasmic IкB $\alpha$ levels were reduced compared with unstimulated cells (Fig. 9, lane 2 compared with lane 1). After $60 \mathrm{~min}$, $\mathrm{I} \kappa \mathrm{B} \alpha$ returned to original levels due to enhanced transcription. Degradation of $\mathrm{I} \kappa \mathrm{B} \alpha$ was suppressed in the presence of sulfasalazine (compare lanes 4 and 2). When cells were preincubated with the proteasome inhibitor MG132, a faint slowermigrating band was detected, representing a modified form of $\mathrm{I} \kappa \mathrm{B} \alpha$ (lanes 6 and 7). This form of $\mathrm{I} \kappa \mathrm{B} \alpha$ is the result of phosphorylation as the appearance of this band could be blocked if extracts were incubated with calf intestinal phosphatase (data not shown). No phosphorylated form of Iк $\mathrm{B} \alpha$ was detectable in protein extracts from cells pretreated with sulfasalazine. Taken together, these results suggest that sulfasalazine interfered with phosphorylation of IкB $\alpha$.

\section{Discussion}

Although inflammatory bowel disease and rheumatoid arthritis are distinct entities, the same pharmacological agents are useful for their clinical treatment. Despite intense research, there are still no specific therapies for these diseases. Treatment is directed towards symptomatic improvement and controlling the disease process. The mainstays for therapy of inflammatory bowel disease remain sulfasalazine, or its compound 5-ASA, and corticosteroids. Current knowledge suggests that the effect of sulfasalazine on disease activity and relapse prevention in ulcerative colitis should be attributed to 5-ASA; its second compound, sulfapyridine, is thought to be responsible for most of the major side effects. Numerous studies have described pharmacological and biochemical properties in relation to the use of these drugs in ulcerative colitis, and more recently in rheumatoid arthritis. However, the possible mechanisms of action remain unclear.

Here we present evidence that sulfasalazine inhibits activation of the transcription factor NF- $\mathrm{B}$, a central mediator of the inflammatory response. In most cell types, NF- $\mathrm{B}$ is kept as an inactive complex in the cytoplasm bound to its inhibitor protein, IкB. Upon activation IкB rapidly degrades, and free $\mathrm{NF}-\kappa \mathrm{B}$ dimers translocate to the nucleus and activate target genes. Here we show by different criteria that sulfasalazine is a potent and specific inhibitor of NF-kB activation in SW620 colon cells: (a) sulfasalazine inhibited TNF $\alpha-$, LPS-, or PMAinduced activation of NF-кB; $(b)$ sulfasalazine suppressed NF$\kappa \mathrm{B}$-dependent transcription; (c) sulfasalazine, but not its metabolic moieties 5-ASA or sulfapyridine, inhibited NF-кB. Only minor changes were observed at high concentrations of 5-ASA or sulfapyridine; $(d)$ sulfasalazine actions were specifically directed against NF- $\mathrm{B}$ activation since it did not inhibit DNA binding activity and transactivation by other transcription factors like AP1; and (e) inhibition by sulfasalazine is the result of preventing nuclear translocation of RelA due to the inhibition of $\mathrm{I}_{\kappa} \mathrm{B} \alpha$ phosphorylation and subsequent degrada- 
A

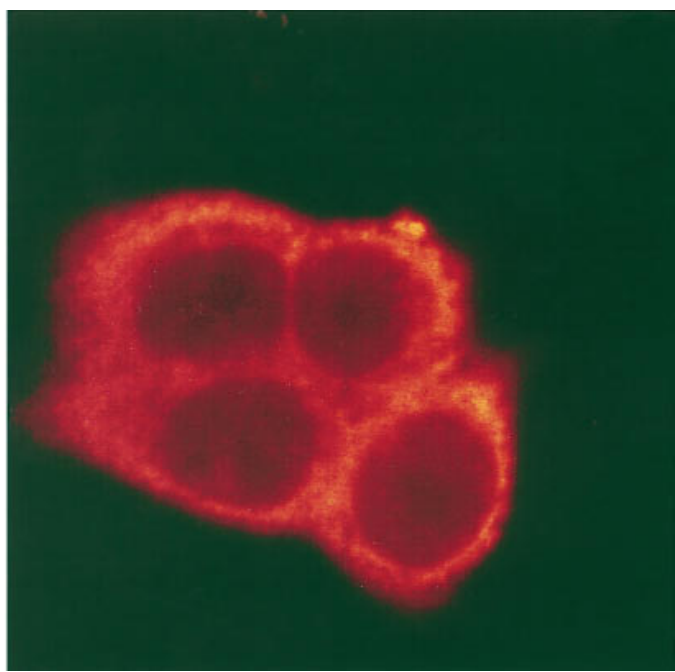

C

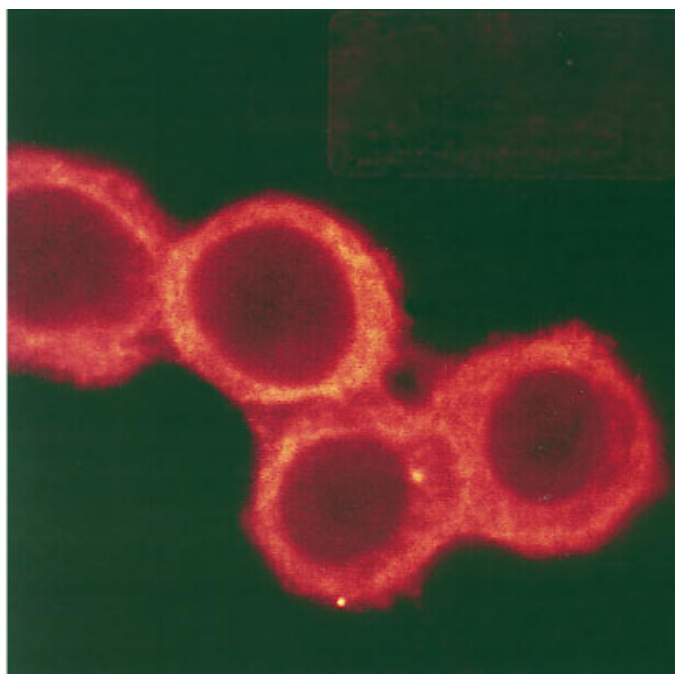

E

inhibitor

TNF $\alpha 150 \mathrm{U}$

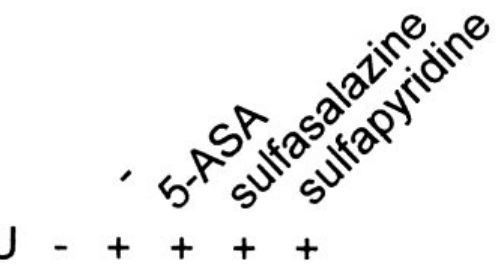

B

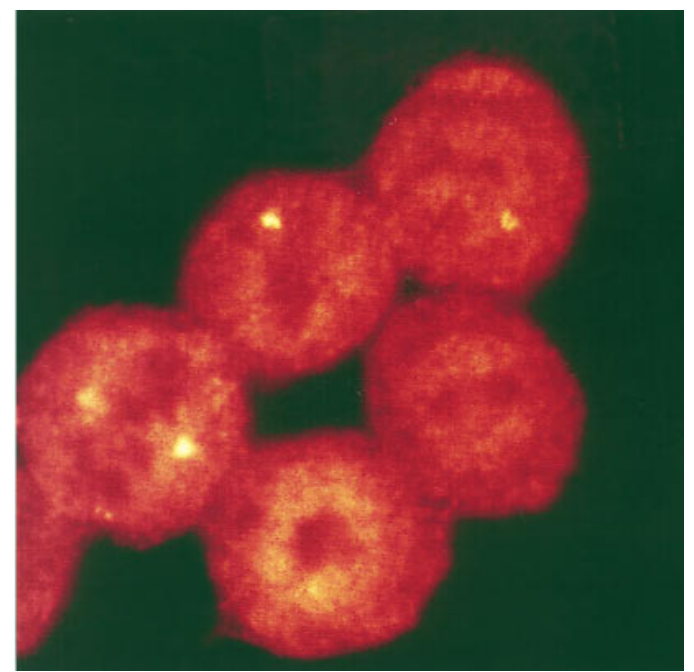

D

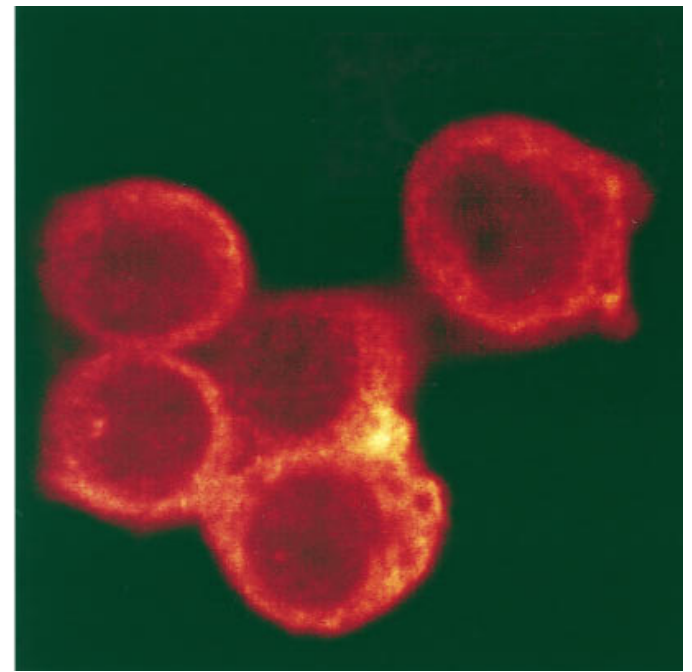

RelA

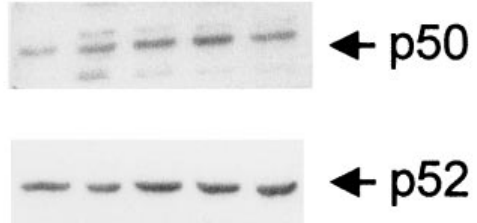

Figure 7. Sulfasalazine inhibits nuclear translocation of RelA (p65). SW620 cells were left untreated $(A)$, stimulated with TNF $\alpha 150 \mathrm{U} / \mathrm{ml}(B)$, treated with sulfasalalzine $5 \mathrm{mM}$ alone $(C)$, or pretreated with $5 \mathrm{mM}$ sulfasalazine followed by stimulation with $\mathrm{TNF} \alpha 150 \mathrm{U} / \mathrm{ml}(D)$. The intracellular location of RelA (p65) was determined by immunofluorescence using an anti-RelA (p65) antibody. Pictures were taken with a confocal scanning microscope (Carl Zeiss), and representative fields are shown. (E) Western blot analysis of nuclear extracts of SW620 cells with specific antibodies against RelA (p65), NF-кB1 (p50), or NF-кB2 (p52). Cells were left untreated (lane 1), stimulated with $\mathrm{TNF} \alpha$ alone $(150 \mathrm{U} / \mathrm{ml}$; lane 2$)$, or pretreated with $5 \mathrm{mM}$ of 5-ASA (lane 3), sulfasalazine (lane 4), or sulfapyridine (lane 5).

tion. We thus propose that sulfasalazine exerts either a direct effect on an IкB $\alpha$ kinase or on another upstream signal.

Several lines of evidence suggest that ROIs function as upstream second messengers in the NF- $\mathrm{B}$ activation pathway.
Treatment of cells with many structurally unrelated antioxidants or overexpression of antioxidative enzymes such as catalase, thioredoxin, or glutathione peroxidase, inhibit NF- $\mathrm{B}$ activation induced by various stimuli $(36,37)$. Scavenging of free 


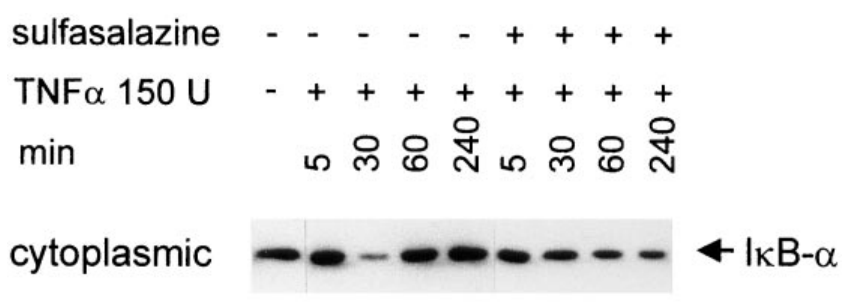

nuclear

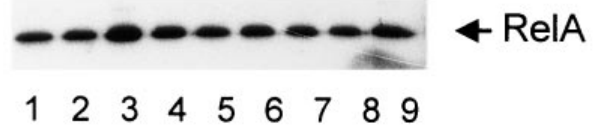

Figure 8. Sulfasalazine blocks IкB $\alpha$ degradation after stimulation with TNF $\alpha$. Western blot analysis of cytoplasmic and nuclear extracts of SW620 cells treated with or without sulfasalazine for $30 \mathrm{~min}$ before stimulation with TNF $\alpha$. At the indicated time points (in min), cytoplasmic and nuclear extracts were prepared. Control samples were processed immediately after adding $\mathrm{TNF} \alpha$. Equivalent amounts of cytoplasmic extracts were analyzed by Western blot as indicated in Methods using RelA (p65) and ІкB $\alpha$-specific antibodies.

oxygen radicals by sulfasalazine has been proposed to cause beneficial effects in the treatment of ulcerative colitis $(16,17)$. This effect could not be explained by inhibition of NF- $\mathrm{kB}$ activation since several previous studies have shown that sulfasalazine and 5-ASA have comparable radical scavenging activities. In this study, sulfasalazine could block NF- $\mathrm{B}$ activation, whereas 5-ASA failed to show any effect. Therefore, it seems unlikely that the effect of sulfasalazine on ROIs could account for its potent inhibitory effect on $\mathrm{NF}-\kappa \mathrm{B}$ activation.

Previously, it has been shown that other widely used antiinflammatory salicylates, specifically sodium salicylate and aspirin, can inhibit NF-кB-dependent transcription $(32,33)$. Half maximal inhibition was obtained with $2 \mathrm{mM}$, whereas $20 \mathrm{mM}$ of sodium salicylate was needed for complete suppression of $\mathrm{NF}-\kappa \mathrm{B}$ activity (32). In this study only marginal effects were obtained using SW 620 colon cells and $5 \mathrm{mM}$ sodium salicylate

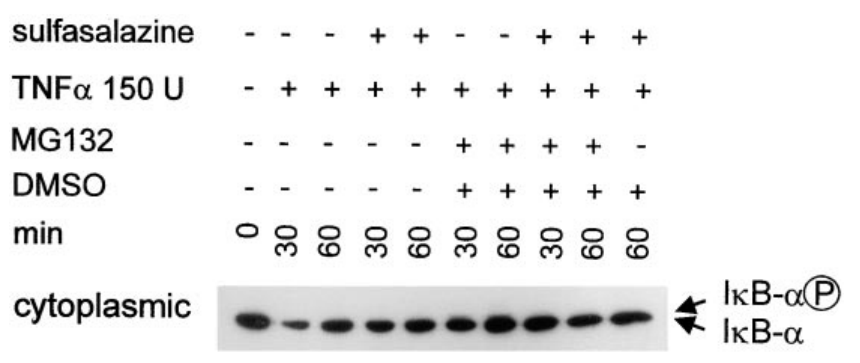

$\begin{array}{llllllllll}1 & 2 & 3 & 4 & 5 & 6 & 7 & 8 & 9 & 10\end{array}$

Figure 9. Sulfasalazine appears to prevent IкB $\alpha$ phosphorylation. Inhibition of in vivo phosphorylation of I $\mathrm{B} \alpha$ after treatment with sulfasalazine. Cells were treated for $30 \mathrm{~min}$ with the proteasome inhibitor MG132 before stimulation with $\mathrm{TNF} \alpha(150 \mathrm{U} / \mathrm{ml})$ in the presence or absence of sulfasalazine. Equal amounts of SW620 cytoplasmic extracts were prepared 30 and $60 \mathrm{~min}$ after TNF $\alpha$ stimulation. Samples were then analyzed by Western blotting using an IкB $\alpha$ antibody. The phosphorylated and unphosphorylated forms of IкB $\alpha$ are indicated (arrows).
( $15 \%$ inhibition) in contrast to sulfasalazine, which mediated $\sim 50 \%$ inhibition with $0.5 \mathrm{mM}$ and complete inhibition at $5 \mathrm{mM}$ concentration. Therefore, sulfasalazine seems to be at least ten times more potent than sodium salicylate. Similar results were obtained using Jurkat T cells. The differences of our data from the previously published results might be due to the different cell types used. Since previous reports used sodium salicylates in doses up to $20 \mathrm{mM}$, we were interested in studying the effect of such high doses in our cell system. Unfortunately, in our hands sodium salicylate was not soluble at this high concentration. Therefore, we cannot rule out increasing inhibition of $\mathrm{NF}-\kappa \mathrm{B}$ activation by sodium salicylate at higher concentrations in SW620 cells or Jurkat T cells. However, it was shown that sodium salicylate acts rather nonspecifically by inhibiting transcription from AP1 and CRE-dependent reporter constructs at the same concentrations as those that blocked NF-кB-mediated transcription (38). Since no specific component is shared between the PMA/inonomycin-inducing NF-кB or AP1 pathways and c-AMP-dependent signal transduction, the authors concluded that inhibition by sodium salicylate is most likely due to a nonspecific effect on cellular kinases. In contrast, sulfasalazine did not inhibit AP1 binding or AP1 dependent-transcription in concentrations up to $5 \mathrm{mM}$.

The concentration of sulfasalazine achieved in inflamed tissue is not known. However, the serum sulfasalazine concentration after an average oral dose of 3-6 g/die is reported in inflammatory bowel disease patients to be $10-15 \mu \mathrm{g} / \mathrm{ml}$ (equivalent to $0.025-0.038 \mathrm{mM}$; 39). Stool concentrations are in the order of $1.25-2.0 \mathrm{mM}$. Interstitial concentrations may be as high as $0.5-1.0 \mathrm{mM}(40)$.

It is generally believed that the active and beneficial component of sulfasalazine in treatment of ulcerative colitis is 5-ASA. However, here we present data that sulfasalazine by itself is an active pharmacological agent with a strong and unique potency to inhibit NF- $\mathrm{B}$ which is not shared by its moieties, 5-ASA and sulfapyridine.

There is increasing evidence from in vivo studies in animals that NF- $\mathrm{B}$ is involved in pathogenesis of chronic intestinal inflammation (41). Lamina propria macrophages of mice with TNBS-induced colitis produced high amounts of proinflammatory cytokines including IL-1, IL-6, and TNF $\alpha$ (41). The genes coding for these cytokines are strongly regulated by NF-кB. Furthermore, IL-1 and TNF $\alpha$ are among the most potent inducers of NF-кB. Strikingly, mice suffering from TNBS-induced colitis could be successfully treated by a single local administration of a RelA (p65) antisense phosphothioate oligonucleotide (41). Similar upregulation of proinflammatory cytokines was found in the colitis of IL-10 deficient mice. This upregulation may also be due to deregulated RelA (p65) activity since it was successfully treated with RelA (p65) antisense oligonucleotides (41). Previously, a suppressive effect of IL-10 on NF $\kappa B$ activation was demonstrated in vitro $(42,43)$. However, IL-10 seemed not to interfere with NF-кB activation in human monocytic cell lines stimulated with PMA or LPS, but rather inhibited the B7/CD28-mediated costimulatory effect of monocytes on CD3-stimulated T lymphocytes. This downregulation might involve inhibition at a posttranscriptional level $(42,43)$. Upregulation of RelA (p65) expression was noted in lamina propria macrophages from patients with Crohn's disease (41). Specific downregulation of RelA (p65) in these cells in vitro resulted in a considerably reduced production of IL-1, IL-6, and TNF $\alpha$. These observations in combination with our 
data support the assumption that the beneficial effect of sulfasalazine on inflammatory bowel disease is mainly due to the inhibition of NF- $\mathrm{KB}$ activation.

Glucocorticoids that are frequently used for treatment of inflammatory bowel disease and rheumatoid arthritis are also suggested to suppress NF-кB activation. In contrast to sulfasalazine, glucocorticoids are thought to induce transcription of $\mathrm{I}_{\kappa} \mathrm{B} \alpha$, resulting in an enlarged Iк $\mathrm{B} \alpha$ pool, and therefore reduced active NF- $\mathrm{KB}$ in the nucleus $(44,45)$.

Previously, it was shown that sulfasalazine inhibited IL-2 production of activated T lymphocytes (12), as well as TNF $\alpha$ and IL-1 synthesis in macrophages (13). Sulfasalazine was at least ten times more potent to suppress antibody synthesis of plasma cells than was 5-ASA (46). These observations can now be explained by the inhibitory effect of sulfasalazine on NF- $\mathrm{B}$ activation. Further studies of the effect of sulfasalazine on NF$\kappa \mathrm{B}$-dependent gene expression in lymphocytes and macrophages may elucidate complex biological properties.

In summary, our data suggest that sulfasalazine, but not its compounds 5-ASA or sulfapyridine, is a strong and specific inhibitor of NF-кB activation, which might explain its beneficial effect in the treatment of chronic inflammations.

\section{Acknowledgments}

We are indebted to Esther Rüber, Janet Köhler, and Roswitha Rittelmann for excellent technical assistance.

This work is part of the doctoral thesis of C. Wahl, and was supported by grants from Deutsche Forschungsgemeinschaft Schm 740/3 to R.M. Schmid and SFB 322 to S. Liptay and R.M. Schmid.

\section{References}

1. Svartz, N., 1941. Ett nytt sulfonamidpreparat. Forelopande meddelande. Nord. Med. 9:544.

2. Riis, P., P. Anthonsien, H.R. Wulff, O. Folkenborg, O. Bonnevie, and V. Binder. 1973. The prophylactic effect of salazosulphapyridine in ulcerative colitis during long-term treatment: a double-blind trial on patients asymptomatic for one year. Scand. J. Gastroenterol. 8:71-74.

3. Hoult, J.R.S. 1986. Pharmacological and biochemical actions of sulphasalazine. Drugs. 32 (Suppl. 1):18-26.

4. Azad Khan, A.K., J. Piris, and S.C. Truelove. 1977. An experiment to determine the active therapeutic moiety of sulphasalazine. Lancet. 2:892-895.

5. Klotz, U., K. Maier, C. Fischer, and K. Heinkel. 1980. Therapeutic efficacy of sulfasalazine and its metabolites in patients with ulcerative colitis and Crohn's disease. N. Engl. J. Med. 303:1499-1502.

6. Sutherland, L.R., G.R. May, and E.A Shaffer. 1993. Sulfasalazine revisited: a meta-analysis of 5-aminosalicylic acid in the treatment of ulcerative colitis. Ann. Int. Med. 118:540-549.

7. Taggart, A.J., V.C. Neumann, J. Hill, C. Astbury, P. Le Gallez, and J.S. Dixon. 1986. 5-aminosalicylic acid or sulphapyridine, which is the active moiety of sulphasalazine in rheumatoid arthritis? Drugs. 32 (Suppl. 1):27-34.

8. Bird, H.A. 1995. Sulphasalazine, sulphapyridine or 5-aminosalicylic acid-which is the active moiety in rheumatoid arthritis? Br. J. Rheumatol. 34 (Suppl. 2):16-19.

9. Carlin, G., R. Djursater, and G. Smedegard. 1989. Inhibitory effects of sulfasalazine and related compounds on superoxide production by human polymorphonuclear leukocytes. Pharmacol. Toxicol. 65:121-127.

10. Rhodes, J.M., T.C. Bartholomew, and D.P. Jewell. 1981. Inhibition of leucocyte motility by drugs used in ulcerative colitis. Gut. 22:642-647.

11. Rubinstein, A., K.M. Das, J. Melamed, and R.A. Murphy. 1978. Comparative analysis of systemic immunological parameters in ulcerative colitis and idiopathic proctitis: effect of sulfasalazine in vivo and in vitro. Clin. Exp. Immunol. 33:217-224.

12. Sheldon, P.J., C. Webb, and K.A. Grindulis. 1988. Effect of sulphasalazine and its metabolites on mitogen induced transformation of lymphocytesclues to its clinical action? Br. J. Rheumatol. 27:344-349.

13. Fujiwara, M., K. Mitsui, and I. Yamamoto. 1990. Inhibition of proliferative responses and interleukin 2 production by salazosulfapyridine and its metabolites. Jpn. J. Pharmacol. 54:121-132.

14. Gaginella, T.S., and R.E. Walsh. 1992. Sulfasalazine: multiplicity of ac- tion. Dig. Dis. Sci. 37:801-812.

15. Grisham, M.B. 1993. Role of reactive oxygen metabolites in inflammatory bowel disease. Curr. Opin. Gastroenterol. 9:971-980.

16. Aruom, O.I., M. Wasil, B. Halliwell, B.M. Hoey, and J. Butler. 1987. The scavenging of oxidants by sulphasalazine and its metabolites. A possible contribution to their anti-inflammatory effects? Biochem. Pharmacol. 36:3739 3742 .

17. Gionchetti, P., C. Guarnieri, M. Campieri, A. Bellusgi, C. Brignola, P. Tannone, M. Miglioli, and C. Barbara. 1991. Scavenger effect of sulfasalazine, 5-Aminosalicylic acid, and osalazine on superoxide radical generation. Dig. Dis. Sci. 36:174-178.

18. Siebenlist, U., G. Franzoso, and K. Brown. 1994. Structure, regulation and function of NF-кB. Ann. Rev. Cell Biol. 10:405-455. $13-20$.

19. Baeuerle, P.A., and D. Baltimore. 1996. NF-кB: ten years after. Cell. 87:

20. Beg, A.A., T.S. Finco, P.V. Nantermet, and A.S. Baldwin Jr. 1993. Tumor necrosis factor and interleukin-1 lead to phosphorylation and loss of IкB $\alpha$ : a mechanism for NF-кB activation. Mol. Cell. Biol. 13:3301-3310.

21. Palombella, V., O. Rando, A. Goldberg, and T. Maniatis. 1994. The ubiquitin-proteasome pathway is required for processing the NF-кB1 precursor protein and the activation of NF-кB. Cell. 78:773-785.

22. Brown, K., S. Gerstberger, L. Carlson, G. Franzoso, and U. Siebenlist. 1995. Control of IкB- $\alpha$ proteolysis by site-specific, signal-induced phosphorylation. Science. 267:1485-1488.

23. Thompson, J.E., R.J. Phillips, H. Erdjumant-Bromage, P. Tempst, and S. Ghosh. 1995. IkB- $\beta$ regulated the persistent response in a biphasic activation of NF-кB. Cell. 80:573-582.

24. Schmid, R.M., N.D. Perkins, C.S. Duckett, P.C. Andrews, and G.J. Nabel. 1991. Cloning of an NF-кB subunit which stimulates HIV transcription in synergy with p65. Nature. 352:733-736.

25. Duckett, C.S., N.D. Perkins, T.F. Kowalik, R.M. Schmid, E.-S. Hunag, A.S. Baldwin, Jr., and G.J. Nabel. 1993. Dimerization of NF-kB2 with RelA (p65) regulates DNA binding, transcriptional activation, and inhibition by an IкB- $\alpha$ (MAD-3). Mol. Cell. Biol. 13:1315-1322.

26. Schmid, R.M., S. Liptay, J.C. Betts, and G.J. Nabel. 1994. Structural and functional analysis of NF-кB. J. Biol. Chem. 51:32162-32167.

27. Chomczynski, P., and N. Sacchi. 1987. Single-step method of RNA isolation by acid guanidinium thiocyanate-phenol-chloroform extraction. Anal. Biochem. 162:156-159.

28. Omary, M.B., L. deGrandpre, M. McCaffrey, and M.F. Kagnoff. 1992 Biochemical and morphological differentiation of the human colonic epithelial cell line SW620 in the presence of dimethylsulfoxide. J. Cell. Biochem. 48:316-323.

29. Schuerer-Maly, C.-C., L. Eckmann, M.F. Kagnoff, M.T. Falco, and F.E. Maly. 1994. Colonic epithelial cell lines as a source of interleukin-8: stimulation by inflammatory cytokines and bacterial lipopolysaccharide. Immunology. 81: 85-91.

30. Schreck, R., P. Rieber, and P.A. Baeuerle. 1991. Reactive oxygen intermediates as apparently widely used messengers in the activation of the NF-kB transcription factor and HIV-1. EMBO J. 10:2247-2258.

31. Schreck, R., B. Meier, D. Männel, W. Gröge, and P.A. Baeuerle. 1992. Dithiocarbamates as potent inhibitors of nuclear factor $\mathrm{\kappa B}$ activation in intact cells. J. Exp. Med. 175:1181-1194.

32. Kopp, E., and S. Ghosh. 1994. Inhibition of NF-кB by sodium salicylate and aspirin. Science. 265:956-959.

33. Pierc, J.W., M.A. Read, H. Ding, F.W. Luscinskas, and T. Collins. 1996. Salicylates inhibit IkB- $\alpha$ phosphorylation, endothelial-leukocyte adhesion molecule expression, and neutrophil transmigration. J. Immunol. 156:3961-3969.

34. Chiao, P.J., M. Shigeki, and I.M. Verma. 1994. Autoregulation of IкB $\alpha$ activity. Proc. Natl. Acad. Sci. USA. 91:28-32.

35. Ito, C.Y., A.G. Kazantsev, and A.S. Baldwin, Jr. 1994. Three NF-кB sites in the I $\mathrm{B}$ - $\alpha$ promoter are required for induction of gene expression by TNF $\alpha$. Nucl. Acids. Res. 22:3787-3792.

36. Schenk, H., M. Klein, W. Erdbrügger, and W. Dröge. 1994. Distinct effects of thioredoxin and antioxidants on the activation of transcription factors NF-кB and AP-1. Proc. Natl. Acad. Sci. USA. 91:1672-1676.

37. Schmidt, K.N., P. Amstad, P. Cerutti, and P.A. Baeuerle. 1995. The roles of hydrogen peroxide and superoxide as messengers in the activation of transcription factor NF-кB. Chem. Biol. 2:13-22.

38. Frantz, B., and E.A. O'Neill. 1995. The effect of sodium salicylate and aspirin on NF-кB. Science. 270:2017-2019.

39. Das, K.M., M.A. Eastwood, J.P.A. McManus, and W. Sircus. 1973. The metabolism of salicylazosulphapyridine in ulcerative colitis. I. The relationship between metabolites and the response to treatment in inpatients. Gut. 14:631-641.

40. Peppercorn, M.A., and P. Goldman. 1973. Distribution studies of salicylazosulfapyridine and its metabolites. Gastroenterology. 64:240-245.

41. Neurath, M.F., S. Pettersson, K.-H.M. Meyer zum Büschenfelde, and W. Strober. 1996. Local administration of antisense phosphorothioate oligonucleotides to the p65 subunit of NF-кB abrogates established experimental colitis in mice. Nat. Med. 2:998-1004.

42. Romano, M.F., A. Lamberti, A. Petrella, R. Bisogni, P. Tassone, S. Formisano, S. Ventuta, and M.C. Turco. 1996. IL-10 inhibits nuclear factor-кB/ Rel nuclear activity on CD3-stimulated human peripheral T lymphocytes. $J$. 
Immunol. 156:2119-2123.

43. Takeshita, S., J.R. Gage, T. Kishimoto, D.L. Vredevoe, and O. Martinez-Maza. 1996. Differential regulation of IL-6 gene transcription and expression by IL-4 and IL-10 in human monocytic cell lines. J. Immunol. 156:25912598.

44. Auphan, N., J.A. DiDonato, C. Rosette, A. Helmberg, and M. Karin. 1995. Immunosuppression by glucocorticoids: inhibition of NF-kB activity through induction of IкB synthesis. Science. 270:286-290.

45. Scheinman, R.I., P.C. Cogswell, A.K. Lofquist, and A.S. Baldwin Jr. 1995. Role of transcriptional activation of $\mathrm{I} \kappa \mathrm{B} \alpha$ in mediation of immunosuppression by glucocorticoids. Science. 270:283-286.

46. MacDermott, R.P., S.R. Schloemann, M.J. Berotvich, G.S. Nash, M. Peters, and W.F. Stenson. 1989. Inhibition of antibody secretion by 5-aminosalicylic acid. Gastroenterology. 96:442-448. 